\title{
THE BANKING INDUSTRY AND DIGITAL INNOVATION: IN SEARCH OF NEW BUSINESS MODELS AND CHANNELS
}

\author{
STANISŁAW FLEJTERSKI,${ }^{1}$ JAKUB LABUN $^{2}$
}

RECEIVED

ACCEPTED

JEL

CLASSIFICATION

KEYWORDS

ABSTRACT
${ }^{1}$ University of Szczecin, POLAND

e-mail: stanislaw.flejterski@gmail.com

${ }^{2}$ University of Oxford, UNITED KINGDOM

e-mail: jakub.labun@new.ox.ac.uk

13 June 2016

21 October 2016

G20 G21 O33

banking, innovation, digital revolution, FinTech, business models

The financial sector plays an essential role in the development of the contemporary economy, which is not likely to ever change due to its systemic nature. However, conventional banking is becoming a thing of the past as significant changes in demographic, societal, technological, economic, regulatory and legitimacy-related aspects of banking reality change the feasibility of present business models, pressuring for radical adjustments. Banks are also finding themselves under pressure from shadow banks, FinTech firms and lower-cost challenger banks as entries to the sector have risen. Non-bank financial institutions have different advantages over traditional banks due to different competencies and while they pose a threat of disruption, they also covet some of the resources that banks have access to. This article is an attempt to review and categorise the main trends affecting the environment of the financial industry basing on various empirical and non-empirical works of other authors, followed by a synthetic overview on how incumbents and entrants are innovating in a race to design a new valid business model. We aggregate those insights to assess the potential of disruption versus equilibrated cooperation using Disruptive Innovation Theory and Core Competencies theory and conclude that convergence between the two types of financial entities is likely, bringing an end to banking as we know it. We project that the business models will be evolving towards an opti-channel approach, whereby continued innovation enables the emerging alliances of banks and FinTech companies to reach the customer via their most preferred channel and offer a highly individualised service. 


\section{Introduction}

Bill Gates made the famous statement that "Banking is necessary, but banks are not" (1994). An academic refinement of this statement can be seen in Merton (1995), who claims that financial intermediaries fulfil 6 key universal roles imposed by the systemic order of the global economy (see Table 1). The functions need to be performed with as much economic efficiency as possible, but not specifically by any particular type of entities. Banks as we know them emerged through the ebb and flow of history to obtain profits by providing the core functions to the rest of economy, and have been doing so efficiently for a long period of time - as competitive pressures from other entities and the users of the financial system should rectify any long run inefficiency.

Table 1. The six essential functions of financial intermediaries

Six universal functions of the financial system

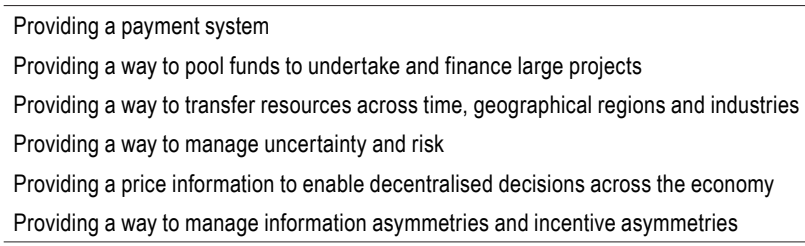

Source: based on Merton (1995).

However, we agree with Merton (1995) that the context for this efficiency is set by the broader macro environment. The logical consequence of this statement is that the way in which the functions are performed would evolve whenever the environment would substantially change. The potential gaps in the competitive landscape brought by changes would incentivise new approaches by offering the possibility of superior economic profits for better stewardship; the economic profit can be received either by a) incumbents who develop the necessary capabilities or b) distinctively new companies entering the sector.

We believe that recent changes warrant a deep economic necessity to adjust business models beyond the classic banking paradigms. Even market imperfections such as high barriers to entry can no longer guarantee survival as the potential economic profit significantly increases due to systemic considerations, which are an order of magnitude greater than any firm-specific abilities to defend its market position. Thus, banks as we know them will either evolve or be replaced due to the significant profit-capture opportunity. The subsequent section will provide a detailed overview of the changes and elaborate our logic of the functional perspective.

\section{Overview of the changes - the pressures on Business Models}

The consensus among the commentators of the financial sectors is that conditions affecting the banking industry have been changing considerably over the past decades. Incremental changes, often too small to be noticed individually, have been accumulating to escalate into significant perturbations, especially in consumerrelated aspects. We categorize those changes into following groups: societal and demographic, technological, economic, regulatory and legitimacy-related. 


\section{Societal and Demographic changes}

The ultimate end-users of financial services are the people. As Ghose et al. (2016) estimate, $46 \%$ of all profits in the sector come from retail banking and 35\% come from corporate banking - given that those two are converging at an increasingly accelerating pace (Fejes, 2014), with some banks already abolishing the separation of those divisions, we can expect that as societal and demographic realities change fundamentally, so will the expectations towards financial services providers and their products.

King (2010) delineates some of those shifts in detail - the appearance of the instant convenience and immediate availability paradigm, already adopted by other industries, from ride-hailing to retail to travel, coupled with the meteoric rise of social media, lifestyle changes, and technology penetration have fundamentally transfigured the desired attributes of a financial service. Capital adequacy, branch network or rates have lost importance for the sake of accessibility, convenience, customization and ease-of-use (Schwarz et al., 2015), the flagship traits of the modern economy that are explicitly observable in its other sectors.

In addition to that, as emphasised by Bergers et al. (2014), the opening of the emerging markets (especially China and India) to a wide variety of financial services that had not been previously widely provided and the emergence of the global middle class, which is projected to increase from 1.8 bn people in 2009 to 4.9 bn people in 2030 (Pezzini, 2012) warrant profound shifts in both the potential aggregated demand size as well as its structure. Therefore, banks no longer serve the same customer they served six or five years ago - the customer's qualities have changed and will change substantially.

\section{Technological changes}

Technological advancements affecting the industry have been monumental and their second-order consequences can be seen as reverberating through all the other of our five categories Among the first-order changes, however, we can categorise the rise of mobile technologies and omnipresence of smartphones and tablets that open radically new and previously unavailable channels of interaction with the customers (Gibbard, 2014).

The rise of computational power has also enabled more sophisticated information gathering and analysing in order to understand the consumer needs. As Big Data in banking industry becomes available, new solutions to old problems will emerge, most notably in respect of risk management and marketing (Schwarz et al., 2015).

Technological advancements also warrant a possibility to redesign internal operations and digitalise workflows. A classic study of Brynjolfsson and Hitt (2000) links them with more efficient managerial systems that support more complexity and other industries have already seen the positive effects of operations digitalization. Yet, the opening of the digital realm also brings threats in terms of security or cyber terrorism.

\section{Economic changes}

Economic factors that warrant feasibility of business models have changed considerably as well. The nascent era of low-yields and the prospects of its continuation affects the feasibility of spread-based models, leaving little room to compete with standard banking product attributes. It also changed the way in which customers make saving and investment decisions, often deterring them from making banking deposits for the sake of alternative investment opportunities. 
We could also observe falling transactions costs brought by the internet and maturing market interfaces, with outsourcing becoming more economically feasible (Laube, 2016), concurrent with the proliferation of professional services firms. This changes the make-or-buy calculus, favouring disintermediation and downsizing.

In addition to that, barriers to entry to the sector have lowered - while still considerable on their own, technology has rendered them easier to surpass, which, coupled with proliferation of entrepreneurship and rising startup culture in many developed countries, allows for new entries, especially from FinTech companies (Bergers et al., 2014),

The economic changes are especially important for our functional reasoning - the less imperfect industries become, the quicker the changes to the modus operandi of financial intermediaries will be as competitive pressures become more enunciated.

\section{Regulatory changes}

The post-crisis regulatory reform has focused on two objectives: to reduce the probability of bank failures and to lower the social cost of failures (Jackson, 2016). This affects the amount of risk that banks can take, and innovation is inherently risky.

Regulation has in general become tighter (Schwarz, 2015). Capital requirements imposed by Basel III and the need of more robust liquidity impact core financial products revolving around balance sheet intermediation hinder the effectiveness of classic revenue generating services.

This is coupled with tighter consumer protection laws and the requirement to treat clients more equally. With the necessity to further separate banking activities and become more transparent to regulators, a revalidation of classic business models is even more urgent.

\section{Legitimacy-pelated changes}

Another repercussion of the recent banking crises, from the major economy meltdown to money-laundering or bribery, is the gradual depletion of legitimacy of banks. The scandals are often linked with the high-geared incentive schemes and governance issues, which Dobbin and Jung (2010) name as one of the two significant causes of the financial crisis. Folkman et al. (2007) even assert that present financial intermediaries have ceased to dutifully serve the economy: due to the incentives disparity and compensation structures, they have started to act adversely against other entities, creating a need for constant reorganization and profiting from fees from needless $M \& A$ transactions. The multifaceted criticism has harmed legitimacy both directly and indirectly, translating itself into lower customer loyalty and worse perception of banks, (Berges et al., 2014); thus, the relationships with customers require more attention.

The changes in public perception of banks are also manifesting themselves in talent acquisition, with the allure of a finance career considerably diminished compared to the first decade of 21 st century. Incumbent banks are facing significant difficulties to recruit graduates from top business schools - as The Economist (2014) reports, in $200744 \%$ of Harvard's MBAs chose to join the financial sector; in 2013, only 27\% embarked upon this career. With increased costs of talent acquisition, gaining competitive advantages becomes more difficult.

For a significant period of time, the 6 essential functions were delivered by the large banks. However, the scope of the delineated changes has opened a number of market gaps to provide more efficient serfdom of the economy changing the context of efficiency and thus demanding business models adjustment The next part of the article will aim to achieve two things - (a) show that we indeed observe increased activity regarding innovation 
amongst incumbents as well as multiple entries into the finance sector and (b) cast an overview of the anatomy of innovation done by two of those groups.

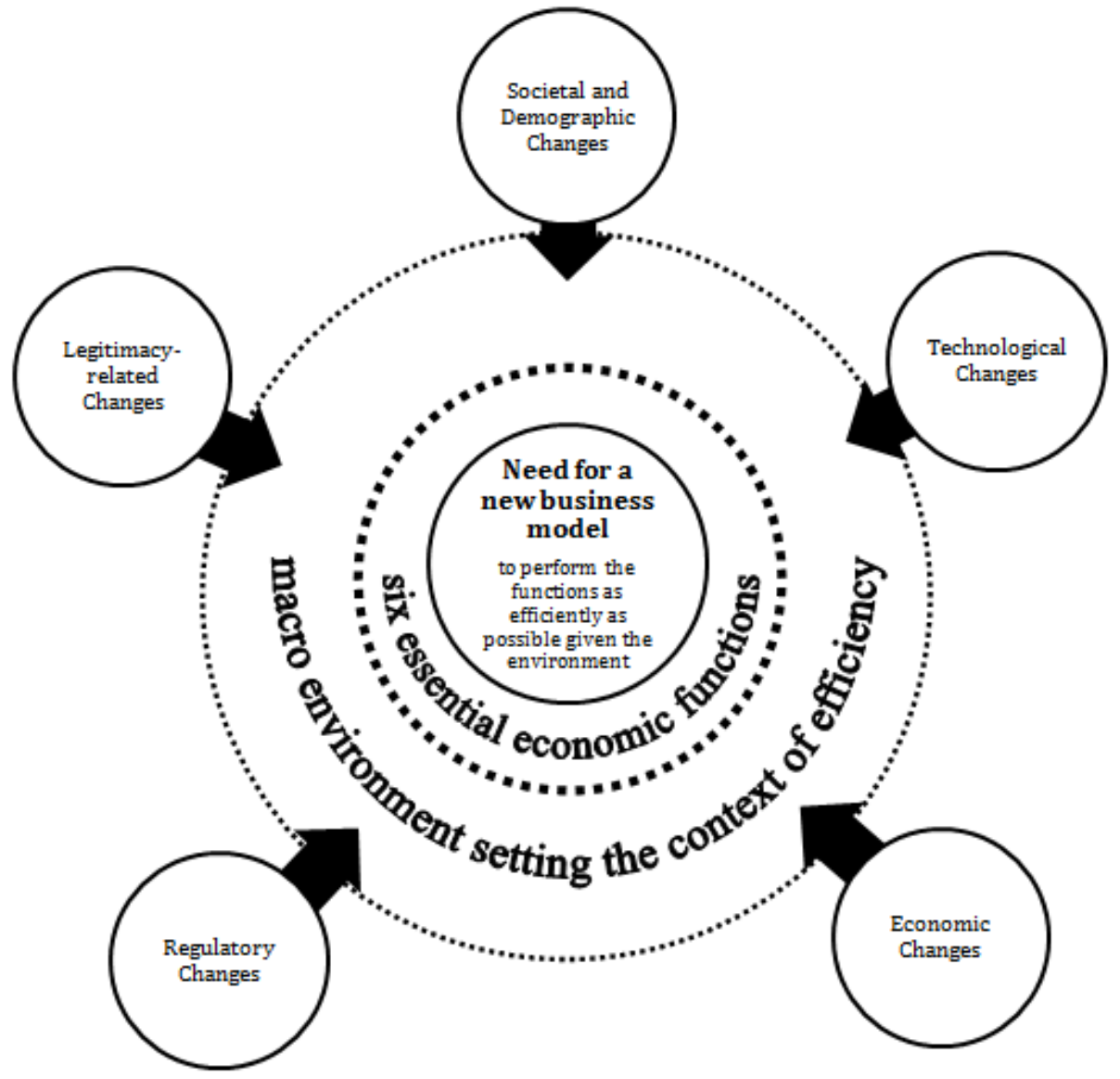

Figure 1. Key trends pressuring a change of business models

Source: own elaboration, based on Bergers et al. (2014).

\section{The Anatomy of Innovation}

For the sake of simplicity, we categorise the entities in financial industry into two groups - the incumbents and the entrants. We will cast an overview of the whole value-chain, segmenting it into 4 steps, starting from the user end. We define innovation as a new solution that increases the value delivered by the offered services. Our findings are presented at the end of this section in figures 2 and 3 , which are used to segregate innovation as radical (being a departure from previously used solutions) versus incremental (building on previously employed solutions) and competition-oriented vs cooperation-oriented. These insights are used to support our final conclusions. 
The way in which banks innovate has indeed changed considerably, largely in response to the changes in environment, increased industry competitions and the FinTech boom, a classic example of entrants who claim to be attempting to dethrone incumbents (note the comment of J. Dimon, the CEO of JP Morgan's to his stakeholders on this issue: "they all want to eat our lunch. Every single one of them is going to try"). The issue of disruption is not so simple however (see The Economist Intelligence Unit 2015 surveys on this issue), and will be discussed in the final part.

In (1) Customer-facing aspects, involving interfaces and interaction channels, innovation of banks has been a mixture of radical and incremental, with more stress on the latter. A distinct feature is the multi-channel and optichannel approach (Gibbard, 2014) that presents a departure from the old business model, reinforced by increased innovation in designing end-user software, such as mobile apps, which has greatly grown on importance (Marous, 2015a) and now allow for the use of other companies' products as well, enabling cooperation. However this still incremental innovation is followed by a radical one, the wearable technology, coupled with radically new security measures. In this category FinTech is outpacing the banks, with better designed apps and more on-line presence (Marous, 2015b).

In (2) Core Services, the innovation of banks is incremental, if there is any at all. Classic depositing or borrowing mechanisms have remained largely unchanged, with most innovation focused on their packaging rather than improving the actual product (note the impact of Low-Yield Environments). However, some banks, most notably those with investment banking branches, have shifted the focus of their revenue generation to advisory, offered as an extension of classic products, and innovate in CRM aspects to ensure that business relations are maintained to maximize gains from non-banking activities. FinTech's major innovation in this category was the platformification enabling peer-to-peer solutions and crowdfunding (Heap, Pollari, 2015) and revolutionary payment systems, but there has been a degree of imitation as well (more lucrative personal accounts, bank-in-a-box, money transferring, more personalised services). We could conversely observe some banks experimenting with peer-to-peer platforms, although on a fast-second basis in reaction to entrants innovation (for the discussion of this strategy, see Markides, Geroski, 2004).

In (3) Back Operations, the outdated IT infrastructures of banks and high switching costs are largely inhibiting radical innovation. However, one distinct example of such is the progressing automatisation of internal operations (Laube, 2016) and implementation of Al. We also observe a trend to down-size balance sheets, introduce big data analytics (Marous, 2015b), although rather speculatively, and introduce more sophisticated management and collaboration systems.

The (4) architecture of inter-divisional interaction for banks has changed as well, largely in response to the operational necessities of the multi-channel approach. Most incumbent banks have also created Venture Capital funds specialising in FinTech funding, support and eventual acquisitions (Laube, 2016), reinforcing the view that they see entrant companies as becoming a stable element of the industry (see The Economist Intelligence Unit, 2015 for a report on this issue). This is accompanied by inceptions of market-watch units (Marous, 2015a), meant to eye potential disruption and seek grounds for partnerships, and occasional independent units whose purpose is radical innovation (see Christensen 1997 for his discussion of such structural solutions), or a pursuit of a fast-second strategy.

Regarding the categorization of innovation done by incumbents, our qualitative review presented in Figure 2 is rather consistent with a classic study of Tushman and Anderson (1986) - we see banks innovate incrementally 
more than radically, or, put in the words of those authors, their innovation is more competence-enhancing rather than competence destroying. However, we also see some attempts at ambidexterity (see Tushman and O'Reliy 2008 for a discussion of this concept).

We also find that banks accept the end of their hegemony and in their innovation prepare to cooperate with entrant companies. We find this result astounding, as such cooperation in face of potential disruption is unusual.

Regarding FinTech innovation, taking the industry mainstream as a reference point, the innovation is more radical, but not entirely so. Quite distinctively, FinTech companies almost always specialise in one service rather than trying to offer plenty and are not bound by legacy technology; this may explain the operational edge over incumbents.

\begin{tabular}{|c|l|l|}
\hline For incumbent banks & \multicolumn{1}{|c|}{ Driven by Competition } & \multicolumn{1}{|c|}{ Driven by Cooperation } \\
\hline Radical & $\begin{array}{l}\text { Automatisation and use of Al } \\
\text { Multi-channel approach } \\
\text { Implementing some peer-to-peer aspects in core } \\
\text { services } \\
\text { Wearable Tech and new security } \\
\text { Introduction of Big Data Analytics }\end{array}$ & $\begin{array}{l}\text { Establishment of Venture Capital funds specialising in acquisition } \\
\text { of FinTech Companies } \\
\text { Establishing Market Foresight teams to eye potential disruption } \\
\text { and recommend buys }\end{array}$ \\
\hline Incremental & $\begin{array}{l}\text { Further development of mobile apps and online } \\
\text { platforms } \\
\text { Reinvention of the existing physical outlets } \\
\text { Balance Sheet minimization } \\
\text { Expanding Core Services (Bank in a Box logic) and } \\
\text { offering advisory and non-banking services } \\
\text { CRM measures to retain trust }\end{array}$ & $\begin{array}{l}\text { Allowing FinTech companies to utilise apps issued by banks } \\
\text { Using FinTech platforms to deliver old services such as payments } \\
\text { participating in peer-to-peer lending as a lender }\end{array}$ \\
\hline
\end{tabular}

Figure 2. The qualitative breakdown of incumbent innovation

Source: own elaboration.

\begin{tabular}{|c|l|l|}
\hline For entrant companies & \multicolumn{1}{|c|}{ Driven by Competition } & \multicolumn{1}{|c|}{ Driven by Cooperation } \\
\hline & $\begin{array}{l}\text { Peer-to-peer platforms and crowdfunding } \\
\text { Payments with smartphones, wearable tech and high- } \\
\text { tech devices } \\
\text { Al advisors and investment managers } \\
\text { Measuring risk with Big Data } \\
\text { Entirely virutalising operations } \\
\text { Reveraging partnerships with non-financial companies } \\
\text { such as retailers } \\
\text { Individually tailored service }\end{array}$ & $\begin{array}{l}\text { Actively seeking banking investors } \\
\text { Keeping structural architecture open to facilitate potential } \\
\text { purchases }\end{array}$ \\
\hline Incremental & $\begin{array}{l}\text { Advancing the excellent app interfaces } \\
\text { Social Media integration } \\
\text { Offering personal classic banking products with more } \\
\text { appealing secondary attributes (money transfers, } \\
\text { individual accounts, stock trading accounts) } \\
\text { Cybersecurity with new modes of authentication }\end{array}$ & $\begin{array}{l}\text { Allowing banks to participate in peer to peer lending and funding } \\
\text { as one side of the transaction } \\
\text { Designing structures with a focus on scalability }\end{array}$ \\
\hline
\end{tabular}

Figure 3. The qualitative breakdown of entrant innovation

Source: own elaboration. 


\section{Implication for the future of husiness models}

We can see how an extrapolation of the trends and the actual direction of innovation in both product and individual business-model aspects corresponds to improvement in efficiency of the core six functions of Merton (1995), with our explicit prognoses presented in Table 2. In this section, we will attempt to answer the question of potential equilibrium in the financial industry and assess the likelihood of a large-scale disruption versus adaptation of incumbents and their coexistence with entrant FinTech companies.

Table 2. The future of 6 core functions

\begin{tabular}{lll}
\hline \multicolumn{1}{c}{ Core Function } & \multicolumn{1}{c}{ The Past } & \multicolumn{1}{c}{ The Future } \\
\hline Providing a payment system & $\begin{array}{l}\text { Physical currency, credit and debit cards, } \\
\text { medium degree of security }\end{array}$ & $\begin{array}{l}\text { Contactless and mobile payments, integration with } \\
\text { smartphones, great degree of security }\end{array}$ \\
$\begin{array}{lll}\text { Providing a way to pool funds for large } \\
\text { projects }\end{array}$ & $\begin{array}{l}\text { Exclusive - only certain groups of people able } \\
\text { to make informed investments }\end{array}$ & $\begin{array}{l}\text { Inclusive - investments open to new groups of people via } \\
\text { crowd-funding and trading platforms; automated advisory } \\
\text { helps with the information barrier }\end{array}$ \\
\hline $\begin{array}{l}\text { Transferring resources across time, } \\
\text { regions and industries }\end{array}$ & Loans and deposits intermediated by the bank & $\begin{array}{l}\text { Direct transfers between agents, low degree } \\
\text { of intermediation; peer to peer lending, uberisation, } \\
\text { convenience, availability }\end{array}$ \\
\hline $\begin{array}{l}\text { Enabling management of uncertainty } \\
\text { and risk }\end{array}$ & $\begin{array}{l}\text { Using the balance sheet to provide liquidity } \\
\text { and absorb risk with a "Big Numbers" } \\
\text { approach }\end{array}$ & $\begin{array}{l}\text { Big Data analytics used to price risk and uncertainty } \\
\text { more accurately }\end{array}$ \\
\hline $\begin{array}{l}\text { Providing price information to manage } \\
\text { decisions across various sectors of the } \\
\text { economy }\end{array}$ & $\begin{array}{l}\text { Exclusive - information expensive and } \\
\text { available to certain groups }\end{array}$ & $\begin{array}{l}\text { Inclusive - updated in real-time, available to more groups } \\
\text { of people via on-line means }\end{array}$ \\
\hline $\begin{array}{l}\text { Providing a way to deal with information } \\
\text { asymmetries }\end{array}$ & $\begin{array}{l}\text { Absorbing information asymmetry costs } \\
\text { with the balance sheet; limited cooperation } \\
\text { between both sides of the transaction }\end{array}$ & $\begin{array}{l}\text { Information gathered both ex ante and ext post from more } \\
\text { sources and analysed more thoroughly; cooperation } \\
\text { between both sides of the transaction to resolve the } \\
\text { problem }\end{array}$ \\
\hline
\end{tabular}

Source: own elaboration, based on Merton (1995).

As hinted before, a peculiar dichotomy emerges from the analysis of the anatomy of innovation of incumbent banks vs. innovation of entrant companies.

First of all, if the Disruptive Innovation Theory of Christensen and Bower (1995) is applied, it may seem that the entrant companies are well poised to cause a disruption that could wipe away incumbent banks. The original theory and its revisited versions (Christensen, 1997; Yu, Hang, 2009) stipulate that disruption is likely when a) entrants create new markets and market channels, b) their value proposition is unique and novel compared to incumbents, c) the innovation comes from down-market (and this is true as initially most FinTech services were risky but more inexpensive alternatives to services of incumbents) and d) the primary attributes of the product are initially considered inferior to those of incumbents' product (in this case, considered less safe and trustworthy, especially in the long-run), but at the same time some secondary attributes are superior, even though they are initially underappreciated (in this case, significantly more convenient and user-friendly service interfaces). Those traits are visible in our analysis of the financial industry (see King, 2010 for more evidence). Therefore, a potential disruption could be expected. 
However, if we view this conundrum through the prism of Core Competencies approach (Prahalad, Hamel, 1990) and the Resource-Based Theory of the Firm (Conner, 1991), both incumbents and entrants possess some valuable and unique resources that the other group does not have access to, nor could easily acquire.

Banks still have (1) considerable customers trust, especially of those with large wealth, (2) large present customer bases and (3) size and capital (see the self-assessment in The Economist Intelligence Unit, 2015) entrant companies can utilize those resources efficiently, and the observed cooperation is a proof of that. While many customers may be tempted by cheaper or more convenient personal accounts offered by some entrants, they are not going to risk their monthly salary by using them as a main account; by partnering with banks, FinTech companies can address this issue. Entrant FinTech companies (1) have access to the top technical talent, (2) are specialised in interfaces and apps design and (3) are allowed to take more risk, thus having more room to innovate. By partnering with them, banks can reach entirely new markets and groups of customers that had been unreachable before, such as emerging markets (Rizzo, 2014) and vastly improve their efficiency. Thus, "fintegration" has become an important goal for both the banks and FinTech companies as both groups begin to realise that cooperation makes them both better off due to resource concerns, presented in Figure 4.

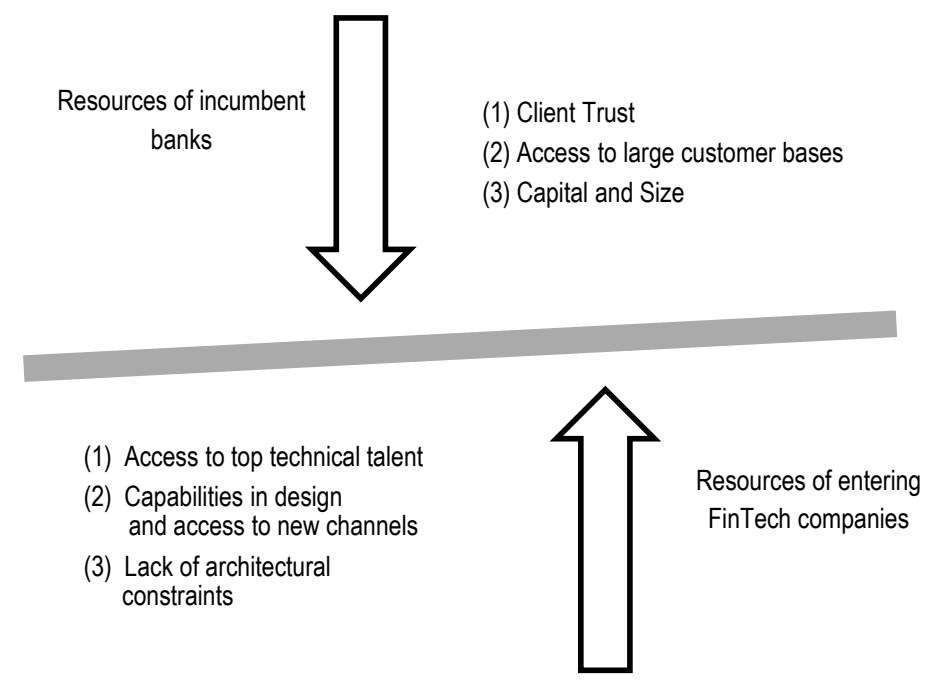

Figure 4. The peculiar resource dependencies of incumbents and entrants

Source: own elaboration.

Thus, we can predict that banks, still largely bound by path dependencies, outdated infrastructures (Haycock, Richmond, 2015), their enormous size and cognitive industry framing effects (see Tripsas 2009 for a study on this) will innovate more incrementally rather than radically even despite their attempts to develop ambidexterity. They will continue to slowly reinvent themselves while entrant companies will fill the gaps and expand the markets, growing on importance and cooperating more closely. We believe that the result of this study points towards future convergence of both of those groups that will result in symbiotic systems of bank-fintech alliances. The unanswered 
question is how the timeline of this transformation will look like and which group will secure a greater share of the new profit.

\section{Conclusion}

We believe to have shown that while the banking system will continue to play a pivotal role in modern economy, it may soon function without banks as we know them. There is no question that technology and other 4 large sources of environmental pressures are changing banking. The new customer - impatient, sceptical, cynical - is the ultimate validator of the new business model, and they are not going back to the old ways.

Beyond multi-channel or omni-channel delivery, an "opti-channel" experience, where the solutions is delivered using the optimal channel based on the customer's individual need seem to be the ultimate business model, towards which the innovation is trying to lead. Rather than utilizing all channels for a specific solution, big data will allow to direct the consumer to the channel that will provide the best and most personalized experience. This may eliminate financial products as we know them today altogether (Marous, 2015b). The challenge for banks is how to find the right balance between mobile and physical branch and how to utilize external competencies of FinTech entrants while not ceding the profits entirely. Thus, we also point to a need to develop new organizational structures that enable successful adoption of the new business model and will not conflict with the results of innovation.

The final conclusion is that the winner of this conundrum should be the customer, who can expect more innovative products and better service in a banking system that will no longer rely on banks as we know them.

\section{References}

Banks? No Thanks! (2014, October). The Economist.

Brett, K. (2010). Bank 2.0. Singapore: Marshall Cavendish Business.

Brett, K. (2013). Bank 3.0. Singapore: Marshall Cavendish Business.

Berges, A. Guillen, M., Moreno, J., Ontiveros, E. (2014). A new era in banking. The landscape after the Battle. Brookline: Bibliomotion

Brynjolfsson, E. \& Hitt, L.M. (2000). Beyond computation: Information technology, organizational transformation and business performance. The Journal of Economic Perspectives.

Christensen, C. (1997). The innovator's dilemma. Boston: Harvard Business School Press.

Conner, K.R. (1991). A historical comparison of resource-based theory and five schools of thought within industrial organization economics: do we have a new theory of the firm? Journal of Management.

Dobbin, F. \& Jung, J. (2010). The misapplication of Mr. Michael Jensen: How agency theory brought down the economy and why it might again. Research in the Sociology of Organizations.

Folkman, P., Froud, J., Johal, S. \& Williams, K. (2007). Working for themselves? Capital market intermediaries and present day capitalism. Business History.

Haycock, J. \& Richmond, S. (2015). Bye bye banks? How retail banks are being displaced, diminished and disintermediated by startupsand what they can do to survive. London: Wunderkammer.

Heap, T. \& Pollari, I.(2015). Fintech 100. Leading Global Fintech Innovators 2015. H2 Ventures \& Financial Services KPMG.

Gibbard, D. (2014). The Flaw in Omni-Channel Banking, Why Bi-Direction Channel Banking is Next.

Jackson, P. (ed.) (2016). Banking reform. SUERF Conference Proceedings, 2.

Laube, H. (2016). Rethinking banking. Credit Suisse Bulletin, 1, 42-50.

Markides, C.C. \& Geroski, P.A. (2004). Fast second: How smart companies bypass radical innovation to enter and dominate new markets (Vol. 325). John Wiley \& Sons.

Marous, J. (2015a). How banking can survive digital disruption?

Marous, J.(2015b). Top 10 retail banking trends and predictions for 2016. 
Merton, R.C. (1995). A Functional Perspective of Financial Intermediation. Financial Management.

O'Reilly, C.A. \& Tushman, M.L. (2008). Ambidexterity as a dynamic capability: Resolving the innovator's dilemma. Research ing organizational behavior.

Prahalad, C.K. \& Hamel, G. (1990). The Core Competence of the Corporation. Harvard Business Review.

Pezzini, M. (2012). An Emerging Middle Class, OECD Observer.

Rizzo, M. (2014). Empowering the Poor via New Technology. The World Bank.

Schwarz, J., Baumgartner, C., Casale, G., Creyghton, A., Dany, O., Massi, M., Tang, Tjun, van den Berg, P. \& Halliday, K. (2015). Five Trends Disrupting the Corporate Banking landscape, BCG Perspectives.

The disruption of banking (2015). The Economist Intelligence Unit Limited.

Tripsas, M. (2009). Technology, identity, and inertia through the lens of "The Digital Photography Company". Organization Science.

Tushman, M.L. \& Anderson, P. (1986). Technological discontinuities and organizational environments. Administrative Science Quarterly.

Yu, D. \& Hang, C.C. (2010). A reflective review of disruptive innovation theory. International Journal of Management Reviews.

Cite this apticle aS: Flejterski, S., Labun, J. (2016). The banking industry and digital innovation: in search of new business models and channels. European Journal of Service Management, 20 (4), 5-15. DOI: 10.18276/ejsm.2016.20-01. 
